Article

\title{
Food for People in Place: Reimagining Resilient Food Systems for Economic Recovery
}

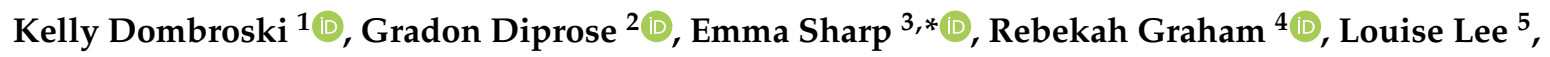 \\ Matthew Scobie ${ }^{6}$, Sophie Richardson ${ }^{3}$, Alison Watkins ${ }^{1}$ and Rosemarie Martin-Neuninger ${ }^{7}$ (D) \\ 1 Te Kura Aronukurangi | School of Earth and Environment, University of Canterbury, Christchurch 8140, \\ New Zealand; kelly.dombroski@canterbury.ac.nz (K.D.); alison.watkins@canterbury.ac.nz (A.W.) \\ 2 Manaaki Whenua-Landcare Research, Wellington 6011, New Zealand; DiproseG@landcareresearch.co.nz \\ 3 Te Kura Mātai Taiao | School of Environment, University of Auckland, Auckland 1142, New Zealand; \\ sophie.richardson@auckland.ac.nz \\ 4 Parents of Vision Impaired NZ Inc, Hamilton 3242, New Zealand; rgraham@pvi.org.nz \\ 5 Open Polytechnic, Lower Hutt 5011, New Zealand; Louise.Lee@openpolytechnic.ac.nz \\ 6 Te Kura Umanga | UC Business School, University of Canterbury, Christchurch 8140, New Zealand; \\ matthew.scobie@canterbury.ac.nz \\ 7 Macmillan Brown Centre for Pacific Studies, University of Canterbury, Christchurch 8140, New Zealand; \\ rosemarie.martin@canterbury.ac.nz \\ * Correspondence: el.sharp@auckland.ac.nz
}

Received: 30 September 2020; Accepted: 2 November 2020; Published: 11 November 2020

\begin{abstract}
The COVID-19 pandemic and associated response have brought food security into sharp focus for many New Zealanders. The requirement to "shelter in place" for eight weeks nationwide, with only "essential services" operating, affected all parts of the New Zealand food system. The nationwide full lockdown highlighted existing inequities and created new challenges to food access, availability, affordability, distribution, transportation, and waste management. While Aotearoa New Zealand is a food producer, there remains uncertainty surrounding the future of local food systems, particularly as the long-term effects of the pandemic emerge. In this article we draw on interviews with food rescue groups, urban farms, community organisations, supermarket management, and local and central government staff to highlight the diverse, rapid, community-based responses to the COVID-19 pandemic. Our findings reveal shifts at both the local scale, where existing relationships and short supply chains have been leveraged quickly, and national scale, where funding has been mobilised towards a different food strategy. We use these findings to re-imagine where and how responsibility might be taken up differently to enhance resilience and care in diverse food systems in New Zealand.
\end{abstract}

Keywords: COVID-19; food security; New Zealand; governance; responsibility; food justice; alternative food movements; diverse economies

\section{Introduction}

The global pandemic has highlighted deep inequalities in capitalist food systems. While Aotearoa New Zealand's pandemic response has been widely praised as successful, and food supply was never in danger, the particularities of the pandemic response still highlighted chronic food insecurity present throughout the country. This paper examines the COVID-19 pandemic response in Aotearoa New Zealand through the lens of food (in)security. We document the contributions of a diverse range of community food organisations to food system support during the pandemic, and examine the possibilities emerging for food systems transformation based on the cross-sector partnerships developed during this time. Drawing on the experiences of community food organisations, we argue 
that resilient food systems must foster diverse food access pathways, while working towards wider community food security in multiple, overlapping ways.

In response to COVID-19, Aotearoa New Zealand's Prime Minister Jacinda Ardern announced a four-level pandemic response system on March 212020 [1,2]. The response levels (1-4) describe different regimes of measures that the public and businesses are required to take in order to reduce the spread of COVID-19, within an effectively closed-border system. Level 1 measures are the least restrictive while Level 4 are the most restrictive. On March 25, Aotearoa New Zealand moved to Level 4 for approximately four and a half weeks, with Ardern describing the approach as "going hard and going early" [3,4]. The Level 4 nationwide lockdown was one of the strictest in the world, with only "essential services" continuing to operate. All people were instructed to stay at home unless they were essential workers. "Essential services" referred to a range of activities, but regarding food provisioning included; the supply, delivery, distribution, and sale of food, beverages, and other key goods essential for maintaining the wellbeing of people, the production and processing of food, and the provision of welfare and social services. While "essential services" did include food production and distribution, there were a number of food services that were excluded and had to close, including butchers, bakeries, restaurants, cafes, bars, and other similar small-scale food retailers that prepare and serve food [1].

The stringent pandemic response meant that in the Level 4 lockdown phase the country effectively eliminated community transmission of COVID-19 for 102 days. Subsequent localised COVID-19 breakouts emerged in August 2020 and were contained through regional Level 2-3 responses. Aotearoa New Zealand's response has been highly successful in terms of human health protection. However, the lockdown restrictions disrupted food systems in the country at every level, from production to manufacturing and processing, through to distribution and ultimately consumption. Significantly, social services were either temporarily closed or had to quickly adapt to the pandemic restrictions. People also had to change their practices around sourcing and eating food. While there was no actual shortage of food in the country in recent months, panic buying and stockpiling of products exacerbated supply-chain issues, as supermarkets could not replenish shelves as fast as they were being emptied [5]. This negatively impacted disadvantaged communities, who are often constrained to purchasing their immediate food needs, and who did not have stockpiled items when supermarket shelves ran low.

In what follows we provide a "rich description" [6] of some of the impacts of the COVID-19 pandemic and associated response to food security in Aotearoa New Zealand. We draw on 20 key informant interviews with participants from across the country to outline how community food organisations, urban farms, social service providers, food banks, local and central government, and food retailers have adapted and responded. The article contributes to research that explores how societies can shift to more equitable food systems, and who takes responsibility in these shifts. Our approach is underpinned by concerns for social justice [7] and empowering local food provisioning [8-10] to ensure people have access to food that meets their material and cultural needs in environmentally sustainable ways. Building on our expertise in community and diverse economies, we understand access to food as resulting from a diverse range of provisioning activities, including transactions made through markets (such as purchasing food from shops and markets) and alternative markets (bartering and trading through social enterprises and community-supported agriculture). Food access also results from transactions that are incommensurable and occur outside markets (such as state allocations, foraging, customary food practices, gleaning, gardening, and gifting or charity transactions) [11-14]. Access to food is shaped by deeply embedded inequalities, both in terms of who has easy access to food and the diverse forms of labour, enterprise, investment, and land/property that enable the production and distribution of it $[7,15]$. There are also deeply held beliefs and subjectivities associated with food, including who is considered a producer, a worker, or a consumer. These shape perspectives around who is considered "worthy" of food as a fundamental right [16,17]. Diversity in the food system offers resilience to a range of potential shocks and crises $[18,19]$, such as those resulting from a global pandemic. 
In what follows, we briefly outline our methods (part 2). In part 3 we provide some context around food security in Aotearoa New Zealand, before describing the impacts and responses to recent events. We draw on Gibson-Graham et al.'s [20] diverse transactions identifier to illustrate the complex and interdependent nature of food security practices. Section 4 concludes with some thoughts on how the recent experiences in Aotearoa New Zealand could encourage transformation of the food system to better address food insecurity, including how and where responsibility might be taken up differently to enhance resilience and care for diverse food systems actors.

\section{Research Approach: Materials and Methods}

This research employed a qualitative approach, undertaking 20 semi-structured interviews. Our interview participants (Table 1) comprised staff and volunteers from 15 community food organisations in the major urban centers of Auckland, Hamilton, Wellington and Christchurch, local government representatives responsible for the emergency response during Level 4 lockdown, staff from central government ministries with responsibility for social services, and staff from one of the major national supermarket chains. Approximately half of these participants were already known to the authors through previous research, while the other half were identified through snowball recruitment [21]. Interviews lasted between 30-60 min and some were conducted over Zoom, while others were in person (depending on the participant's preference and associated Level 2-3 restrictions). Interviews were recorded and transcribed by the respective interviewers. This paper's first author undertook an iterative thematic analysis approach to code themes across the interviews [22]. Given our underpinning qualitative approach and small number of participants, we did not quantitatively count the significance of each theme (e.g., 15/20 participants described ... ). Such an approach would not be appropriate given the different roles and contexts of our participants, nor would counting provide the kind of 'rich description' we sought. Instead, we identified broad themes that emerged through the interviews and sought to illustrate these with quotations that simultaneously illustrated the diversity of experiences, while also pointing to how these converge around concerns for food justice and empowering local food provisioning. Research ethics approval was granted through two ethics applications from the University of Canterbury HEC 2020/25] and [HEC 2020/21/LR-PS].

Table 1. Description of Interview Participants.

\begin{tabular}{ccc}
\hline Number of Participants & Region & Range of Organisations \\
\hline 6 & Auckland & $\begin{array}{c}\text { Urban farm, community meal initiative, food rescue, } \\
\text { food bank, food hub, marae garden }\end{array}$ \\
\hline 5 & Waikato & $\begin{array}{c}\text { Food rescue, food aid, local government, community } \\
\text { organisations }\end{array}$ \\
\hline 6 & Wellington & $\begin{array}{c}\text { Central government, local government, food rescue, } \\
\text { national food collective, national supermarket }\end{array}$ \\
\hline 3 & Christchurch & Urban farm, food bank, community organisation \\
\hline
\end{tabular}

\section{Results and Discussion}

\subsection{Food Security in Aotearoa New Zealand}

Food security first emerged as a discourse in Aotearoa New Zealand in the 1970s. The current commonly used definition for food security comes from the 1996 World Food Summit: "Food security exists when all people, at all times, have physical and economic access to sufficient, safe and nutritious food that meets their dietary needs and food preferences for an active and healthy life" [23]. Food security implies sustained access to sufficient food for an active, healthy life without having to resort to emergency supplies or socially unacceptable coping strategies [24]. Conversely, food insecurity exists whenever the "availability of nutritionally adequate and safe foods or the ability to acquire acceptable 
foods in socially acceptable ways is limited or uncertain" [25]. Put simply, food insecurity means having insufficient access to socially, culturally, and nutritionally appropriate food that is safe to eat.

The COVID-19 global pandemic poses significant challenges to food security, particularly with regards to food access, availability, and stability [26]. The full global effect of COVID-19 on food systems has not yet been realised. What is becoming clear is that the pandemic has the potential to significantly exacerbate existing socio-economic inequalities [27], impacting those who are already experiencing food insecurity disproportionately [28]. There is emerging evidence of this already happening in Aotearoa New Zealand and elsewhere [29]. Ensuring food security requires managing risks and uncertainty around:

- Food access, including: legal, social, and economic access; physical access and geographic distribution; cultural, traditional, or indigenous customary rights

- Food availability, including: volumes of domestic production and imported food that provide sources of dietary energy

- Food stability, including: the effects of climatic variability and other disruptions like pandemics on food access and availability

- Food utilisation, including: designation, perceptions, and management of food waste, public health/sanitary aspects, and water, or what are sometimes called 'non-food dimensions' that impact how people access and use food and how it contributes to people's wellbeing.

Aotearoa New Zealand is one of few countries in the world that could be self-sufficient and contribute to global nutritional needs at the same time [30]. Forty-five percent of Aotearoa New Zealand's arable land is dedicated to the production of food, with farmers annually exporting enough food to feed 20 million people, four times Aotearoa New Zealand's population of approximately five million [31]. Nevertheless, the food price index in Aotearoa New Zealand has steadily increased, with fresh fruit and vegetables in particular becoming increasingly expensive [32]. Currently, almost one in five children (19.0\%) live in severe to moderately food insecure households [33]. Experiences of food insecurity are not shared equitably, with marginalised groups such as disabled people [34], Māori (Indigenous people of Aotearoa New Zealand) and Pasifika [35], and those in receipt of state welfare [36] disproportionately experiencing food insecurity. Geography also matters when it comes to accessing suitable food. For example, while areas of higher social deprivation in Aotearoa New Zealand tend to have greater density of food outlets [37,38], there is a considerable concentration of fast food and takeaway outlets, creating what Sushil et al. [39] and others term "food swamps." The car-dependent nature of transport systems also exacerbates inequities both through geographical access and financial costs of maintaining a vehicle $[40,41]$.

In capitalist welfare states such as Aotearoa New Zealand, the key limiting factor to sufficient food is not a lack of food supply, but rather insufficient resourcing to purchase or access food [15]. The dominant solutions to this tend to narrow to either increasing income for people or reducing other fixed costs so that people can afford to purchase food through market transactions. While we wholeheartedly agree with these solutions, in what follows we highlight the role of alternative and non-market responses to food security. We suggest that since COVID-19, food security has become a common good for the "team of five million", the community invoked by Prime Minister Jacinda Ardern in her COVID-19 communications. Like any common good, the community must pay attention to access, benefit, use, care and responsibility with regards to the resource being made common [20]. Such a common good is at the heart of a community economy of food security. We argue that a community economy of food security emerges from diverse economic practices that more consciously facilitate food secure communities in terms of access, availability and stability of food systems. A community economy of food security is one which organises itself around a particular, community-specific response to shared concerns. Key concerns of a community economy can be distilled to surviving well, distributing surplus, encountering others, consuming sustainably, maintaining commons, and investing in future generations [20]. These concerns provide a useful lens through which we can view 
the work of Aotearoa New Zealand's food organisations. They expand the food security concerns of access, availability, and stability, and challenge us to think more creatively about how food secure systems might be enacted. These concerns became a point of connection between us as researchers working in and studying food justice, and community participants working in the same area. In what follows we discuss our results with reference to these shared concerns for food justice and security, and the key themes of the participant interviews.

\subsection{Assembling a Food Security Community}

Participants noted that prior to COVID-19, 'food security' as a term was not really used in everyday language, either by central government or social service providers. An employee from a national food collective noted that food security "wasn't a word that anyone ever talked about, so we were all constantly using the words like 'food poverty' or 'food hunger". A central government employee described how, prior to 2019, the interconnected components of food security (access, availability, stability, utilisation) were not considered in a coordinated way by the government [42]. Rather, different aspects of food security were responded to by assorted government ministries, community groups, social service providers, and businesses in various, and at times contradictory ways. For example, the Ministry for Primary Industries focuses on the production and availability of food and regulates food safety, but primarily from a productivist export and sale focus. The Ministry of Social Development provides some access and stability through welfare support, including unemployment benefits, emergency accommodation, and emergency food grants. The Ministry of Health funds a raft of healthy eating, nutrition education, and food safety initiatives that are delivered by local District Health Boards. Some local councils provide funding and support for food-related services, such as urban food production, community gardens, and food rescue, partly addressing both access, availability, and utilisation.

Community organisations, not-for-profits, and social enterprises operate across all aspects of the Aotearoa New Zealand food system. This includes addressing availability through growing and selling food (community gardens, urban farms, farmers markets, community-supported agriculture), access through redistributing food (food rescue, free stores, food banks, community pantries, community meals, and co-operatives), stability through ongoing activism to transform food systems for improved human wellbeing, and utilisation (re-distributing surplus food as food rather than waste). Individuals and groups also engage in more 'under the radar' practices such as dumpster diving, foraging, and guerilla gardening $[13,43]$, again, addressing access and availability and stability in innovative ways. Organisations and their practices are informed by diverse approaches, politics, and priorities. For example, 'free stores' re-distribute food without requiring recipients to complete eligibility criteria because the free-store goals are aligned with access to, and utilisation of, surplus [44]. In contrast, most established food banks require recipients to undergo eligibility and screening requirements, often in response to funders' concerns (and wider political debates) around fostering 'independence' from the welfare state [45].

In partial response to this diversity of practices and growing concerns around the role of charities, three major social service providers (Salvation Army, Auckland City Mission, New Zealand Council of Christian Social Services) began a conversation in 2018. However, as an employee of a national food collective notes, the conversation quickly shifted to wider structural questions around the nature of 'charity', the retreat of the welfare state, neoliberal responsibilisation, and the entrenchment and professionalization of non-governmental organisations in social service provision since the 1980s [46,47]:

“[D]oes food parcelling generate more food parcelling? Does this actually solve what we would call food insecurity or have we become part of the mechanism for creating food insecurity, or are we now a part of a dependency system that government relies on in order to meet a level of need within our community that could and perhaps should be met in another way." 
These structural reflections were considered in subsequent hui (meetings) throughout 2018-2019 and resulted in engagement with representatives from Aotearoa New Zealand food producers, the agri-business sector, food retailers, and food distributors to explore potential solutions, with a focus on structural systems change. A partnership between six national social service providers and the Ministry of Social Development was negotiated which resulted in the creation of Kore Hiakai Zero Hunger Collective. Kore Hiakai's purpose is to focus on structural change, best practice, and collaborative approaches to food rescue, and redistribution. Our participants noted that these engagements throughout 2018-2019 facilitated an important national cross-sector discussion around the term food security and moved beyond social service/charity provision and the often silo-ed nature of food production and distribution. Participants described how the relationships facilitated through these hui had important flow-on effects that shaped the response during the 2020 Level 3-4 lockdowns in particular.

Participants described how the increasing use of the term 'food security' firstly through the 2018-2019 hui, and then during the COVID-19 response enabled a community of concern to assemble around the concept. The rise of the term 'food security' and the series of hui that connected different people, organisations, and businesses involved in food also helped to create the understanding that food security was a national 'common good' that required action and responsibility from many, thereby helping to frame food as a commons. Drawing on Cameron et al.'s [48] framing, we could say the community 'learned to be affected' by the different components of food security and had an increased capacity to act when Levels 3 and 4 occurred. We now turn to describing the effects of the Level 3-4 lockdowns on food organisations and how they responded. We have organised what follows into three loose themes that reflect the shared experiences of our participants.

\subsection{Responding to Shared Concerns around Food Security}

\subsubsection{Mapping the Diversity of Local Food Security Practices}

Participants described a relatively similar process in terms of responding to the pandemic and COVID-19 Level system. Participants (except those working for supermarkets) noted initial confusion around whether they were considered an 'essential service', and if so, what they would need to do to continue operating safely. Some local government and service provider participants created local and national maps that identified which food organisations existed, which could operate, what they needed to operate safely (for example, supplies of personal protective equipment (PPE) such as masks), and what their capacity for distribution was. While there were differences across regions, these maps were used to facilitate regional meetings. This mapping revealed the significant extent and diversity of food organisations and practices that had been operating, and for some regions, was the first time this had been attempted. For example:

"COVID had me reaching out to every food bank, food pantry, that we could find and calling them and, 'Are you open? Are you not? Do you need PPE? What are your numbers looking like?'” (local government employee)

"I literally had a map of the Waikato on my wardrobe door and every day I was going, have I spoken to that community, have I spoken to that community" (regional social service organisation employee)

"In the early days prior to Level 4 and during, I did a quick scan of community food organisations including food rescue, food banks and other support services to assess needs, check whether they were operating and explore how supermarkets could assist" (supermarket employee) 
"After that first 10 days [of Level 4], we knew that we needed better data, so we hacked together (from scrounging stuff off the internet and what we knew talking to people, getting as much information as possible) a list of around 230 [national] food banks or Pātaka Kai organisations and began to communicate with them." (national food collective employee)

Once organisations had confirmed they met the definition of an 'essential service' and the state of national emergency was confirmed (thereby opening up funding through the Civil Defence Emergency Management Act 2002) central and local government staff moved quickly into 'response' mode to channel resources through those organisations that could operate. The asset mapping served multiple purposes, it was a way to quickly identify needs and capacity and redirect both government resources and philanthropic donations, and inform the wider public about where to go for certain services or how to contribute. There was a range of criteria used to determine whether/how funding was allocated. For example, in Wellington, community organisations had to show they had a track record working with food and that demand for their services had increased due to COVID-19 and the pandemic response. Our participants recounted different examples of how resources were used. For example, council staff used civil defense funding to distribute PPE to community groups, provide emergency money for community organisations' staff wages, and bought food in bulk so community organisations could then distribute it through their networks. Partway through Level 4 one of the major supermarkets committed to donating over NZ\$1 million to a 'social good' community fund, and let community food organisations order food through their supply chains to obtain discounted rates.

Participants described increased demand for food during the COVID Level 3-4 lockdown(s). While the extent of this increase varied across organisations and regions, for most it was between $300-400 \%$ times the usual demand, with some areas/organisations experiencing increases of up to $900 \%[49,50]$. Participants noted that the extent of the demand took them by surprise and attributed the increase to a combination of three factors: unaccounted-for not-for-profit operations, closure of smaller food providers, and loss of employment/income and thus reduced capacity to purchase food.

The first factor was the unaccounted-for diversity of Aotearoa New Zealand's non-for-profit food distribution systems that essentially ceased overnight. Many smaller food banks, meal services and 'free stores' co-ordinated by churches, located in people's homes, or organised by community centres had to pause operating during Levels 3-4, because they were either not registered as an 'essential service', were unable to adapt to increased health and safety or logistical requirements, or their volunteers were unable to work due to their age /health profile. Included in this were the myriad of social services that include some aspect of food provision (e.g., youth groups, drug and alcohol services, church meals, school breakfast clubs), as well as the more informal gifts and sharing that occurs through families and communities. Participants noted that the significant contributions of these non-market and not-for-profit practices had previously been unrecognised. For example:

"Having done this environmental scan ... [it was clear that] there was going to be a shortage of food. This is the end of March; at that time we thought the shortage was going to be about 1500 meals a week [in the Waikato]. In fact it turned into more like 5000. It was just staggering. The things that we didn't allow for, in [local town] for example, there's a lady who, with her friends every Sunday morning was preparing 80 meals for the congregation on a Sunday night to come back for a meal together. So that stopped. For those people who had got very used to having their Sunday dinner, every Sunday, in the support of that church environment, that was just gone." (regional social service organisation employee)

"I think that they are used to the connection of people of whānau, especially for Māori are very important and we all eat together as a group. When I say as a whānau-it's all that togetherness... They are used to auntie calling in and dropping and it's always 'here, here is a bottle of something, here is a bread that I made'. Now all that sharing that stopped!" (food bank manager) 
The second factor was the closure of smaller food providers where transactions around food occur, including farmers markets, cafes, butchers, restaurants, hotels, and fast-food providers. The closure of these businesses and distribution services essentially funnelled the bulk of market food transactions through supermarkets. These changes played havoc with supply chains, affecting both producers and consumers. For example:

"When lockdown happened and you could no longer run a fruit and vege market, you removed $60 \%$ of the [Auckland] supply chain overnight. The two biggest [fresh food] markets are in South Auckland, so you took the access to market away from those who are most food insecure, and the difference with markets is that prices tend to be lower [than supermarkets] and the grower gets more from the bite of that cherry. Not only were you affecting families in that space who could no longer purchase what they could previously purchase for the price, you were actually affecting producers... Really interesting things like the cost of a $10 \mathrm{~kg}$ bag of potatoes [from a market], it was equivalent to a cost of $3.5 \mathrm{~kg}$ of potatoes in [supermarket]. You think of a family trying to feed 14 people in their household, a $10 \mathrm{~kg}$ bag of potatoes is really helpful, a $3.5 \mathrm{~kg}$ bag of potatoes isn't going to go very far." (national food collective employee)

"[name] had a contact, who knew some farmers down south .... And they brought up a tonne of vegetables like carrots, onions, pumpkin [that they could not sell because of Level 4 lockdown]. They peeled it all and they turned it into a soup initiative for the local schools and libraries. They did that ... to give back to the community because they had all this produce that was going to go to waste." (food hub manager)

The third factor was loss of employment/income and the furlough of workers which increased reliance on available emergency food services.

Participants described how the funneling of supply and distribution through supermarkets, together with the loss of incomes created geographic and financial access barriers. Combined with public transport restrictions and high demand on taxi and Uber services many people were simply unable to access food from available supermarkets. For many parts of New Zealand, smaller towns and rural areas in particular, Uber is not available, and taxis are limited. Participants suggested it was the combination of these factors that exacerbated existing inequities and created sudden demand from people they would not typically support. This included people who could afford to buy food but who felt unsafe entering a supermarket, people who did not have their own private motor vehicle and who could not afford private taxis, and migrant workers and international students summarily dismissed by their employers and who did not have recourse to state welfare or familial support networks. For example,

"One of the things that we are recording is job loss, income reduction or not entitled to benefits. Because there are a lot of migrant workers, or workers that are on work visas here only, and they are not residents in New Zealand, so they are not entitled to any benefit at all...they can't get out, they got no work and they got also no money, and they are not entitled to any money". (foodbank manager)

The combination of these factors meant that food security suddenly became a national and pressing matter of concern for many New Zealanders. One effect of this was that the unprecedented demand for food services heightened their visibility and public profile—-both within communities and from central and local government. Participants described this in various ways-as getting "free marketing" (urban farm manager), people "stumbling on" an organisation for the first time (low-income community garden facilitator), seeing an increase in donations and volunteers, greater government support, and being viewed as an "essential service." In some cases, this led to community members seeking to learn the skills to grow their own food, or volunteer at gardens, and thereby access food in different ways. For example: 
"More volunteers ... definitely ... Which I guess is partly due to people wanting to learn more but also there are more people around now who are out of work and don't necessarily have great prospects of finding something that soon ... We're definitely experiencing some of the post-COVID demand for food growing ... for people to learn the skills for growing their own food." (urban farm manager)

"It was actually quite good for us in a lot of ways because there were a lot of people in the community that we're seeing actually [for] the first time." (low-income community garden facilitator)

In other cases, it led to greater central and local government support and recognition of the role not-for-profit food services provide. For example, the founder of a food rescue organisation noted that since COVID-19 there has been significant investment in food rescue from central government (primarily the Ministry of Social Development). This combination of circumstances served to make visible the contribution of the existing diversity of Aotearoa New Zealand's food system which was not immediately apparent to many until it was disrupted during Levels 3-4.

\subsubsection{Adapting to Change: Logistics, Infrastructure, and Capacity}

Once a food organisation had confirmed they were considered 'essential' and could continue to operate, they had to implement new health and safety practices. These included rostering staff in different teams to create separate 'work bubbles', accessing and using PPE (gloves and masks), and new cleaning practices (regular hand washing, sanitising surfaces that touch food, and vehicles). All community food organisations had to reconsider how they sourced food as many of their pre-COVID supply chains were disrupted to some extent. They also had to work out how to redistribute this food through contactless delivery. For some participants' organisations these changes were relatively simple, while for others they involved significant adaptations and a range of transactions. The following five examples illustrate the diversity of transactions that were used to quickly adapt and provide food to people.

Example 1. A major supermarket chain adapted existing online food purchasing systems and worked with both their own couriers and the Student Volunteer Army to prioritise deliveries of purchased food to vulnerable consumers. The Student Volunteer Army emerged out of the Christchurch earthquakes over 2010-2011 and supports volunteering opportunities for young people across Aotearoa New Zealand.

Example 2. An urban farm in Christchurch used its online community of supporters to quickly redirect food intended for (now closed) restaurants, to urban and suburban vegetable deliveries. Because the urban farm was connected to the wider network of Canterbury organic farmers, they were able to act as a kind of 'broker', distributing surplus vegetables from other farmers who needed new markets. In this case, the predominantly middle-class consumers responded with compassion to the needs of the urban farm, which also doubles as a caring workplace for youth interns who in turn suddenly became essential workers. The urban farm passed on that care to regional farms struggling to sell their produce with restaurants and small vegetable shops closed and supply chains disrupted.

Example 3. A Waikato-based volunteer service that had provided on-site cooked meals to people had to make significant changes as they could no longer do this at Levels 3-4. Working with Civil Defence they brokered a partnership with Montana, a commercial catering company who were paid using civil defence funding to cook and deliver meals to people. Montana was thus able to keep staff employed, and food was able to be distributed to those who needed it through the volunteer service's existing community networks. This example reflects other actions taken after natural disasters in New Zealand where infrastructure and labour within the for-profit market was quickly adapted through public funding and relationships to address community food insecurity and response [51]. 
Example 4. A food hub in South Auckland that, pre-COVID19, made hangi (a traditional Māori method of cooking using heated hot rocks buried in a pit oven) on site to provide culturally appropriate food, shifted to pick-up and delivery of family boxes to ensure access continued in their community.

Example 5. A charitable organisation re-deployed its staff from other areas into its foodbank operation. The staff were divided into isolated 'bubbles', which focussed on different areas of the foodbank (chiller, fresh packing, administration, and driving/delivery).

Disruptions to supply chains had a number of other flow-on effects, creating shortages of certain foods and surplus of others. For example, the closure of hotels and restaurants led to a surplus of thousands of live pigs and chickens that would normally be processed and used by the hospitality and restaurant sectors. The surplus posed significant animal welfare issues, so the Ministry for Primary Industries agreed to purchase a portion of surplus food at cost and donated it to food rescue organisations for redistribution [52]. Central and local government facilitated partial redistribution of surplus, with community food organisations brokering new arrangements directly with commercial operators. For example, one Wellington-based food rescue and social service provider brokered a relationship with Turners and Growers (a national fresh fruit and vegetable producer) to enable more efficient distribution of surplus fresh food.

Participants noted that food surpluses resulting from disrupted supply chains had significant impacts on their logistics and infrastructure. To manage these significant increases in the volume of food, community organisations required additional infrastructure. For example, one food rescue organisation described how they moved from crates to pallets to manage increased volumes of food. This meant that they then needed new operating procedures, including changes to warehouse layout and forklifts. Similarly, another food rescue organisation shifted to new premises to increase operational capacity. Both organisations had their infrastructure needs met through a combination of local government funding, philanthropic donations, and ongoing relationships with a major supermarket chain. One participant explained how the supermarket chain has committed to training their staff to use forklifts and thereby meet required health and safety requirements. The following example provides an account of the importance of infrastructure when managing food surplus:

"I rang [name] at [local town] and said, I've got 400 chickens, how can I get them to you? And it highlighted that, in that particular community, there aren't the fridges for the food storage. So [while] they had a community of 200 households that would love to have roast chicken for dinner, actually, logistically they weren't going to be able to do it. In the end, the chickens went to [a local religious camp] who held them over the weekend, people from [area] came in and picked up the chickens. But we all thought that they would be individual chickens, you know, the way you get them from the supermarket. No!! They come in bags of 10 at a time that were all stuck together!! So one of the elements of this whole food security thing, is you don't know what you're getting. So when someone says, we've got this wonderful supply of food, one of the things I've discovered we cannot make an assumption about what form that comes in and how easy it is going to be to handle at the other end." (regional social service organisation employee)

The temporary closure of smaller community food distributors resulted in a form of consolidation where larger organisations with staff, capacity, and suitable infrastructure became central to meeting food needs. For example, an established food rescue organisation in Wellington went from working with approximately 92 food distribution partners to 30, with the bulk of food distribution channelled through an even smaller number of partners, including iwi rūnanga (tribal groups) and marae. Three key factors shaped community food organisations' ability to adapt: staffing, infrastructure (chillers, food storage facilities, trucks, pallets and crates, forklifts), and relationships within their community. Those organisations with paid staff, facilities (or who could partner with others and had personnel 
who were able meet health and safety requirements), and which had good existing relationships within their community were able to adapt and respond most easily.

Prior to COVID-19, central government and philanthropists had been working with food rescue groups (primarily KiwiHarvest) and others to explore the potential for a national food rescue network. COVID-19 and the associated Level 3-4 responses accelerated the implementation of the New Zealand Food Network (NZFN). NZFN started operating during Level 4 and has obtained NZ\$5.5 million in funding from the Ministry of Social Development over the next two years. The ethos underpinning this initiative is essentially the creation and management of a food surplus common; the NZFN will act as broker to obtain and store surplus food and redistribute this across the country to community partners, in the process gaining efficiencies of scale while respecting local autonomy.

In order to manage this new food commons, the NZFN has had to quickly develop a series of complex processes. These include creating an online registration system for food donors and a legal agreement to manage food safety and responsibility, food inspection and re-packaging processes once surplus food is delivered, and an online registration system to equitably manage and then allocate requests for the surplus food to community organisations. These processes are often time-pressured given much of the surplus food is often close to best before dates. As the founder of a food rescue organisation noted, the system is designed so "you're keeping control in the hands of the people who are working in the community and know what is needed at the grassroots level."

The adaptations described above and the emergence of the NZFN illustrate how surplus food can connect different actors and create a national common. While some participants were positive about the creation of the NZFN, particularly in terms of the national efficiencies of scale and distribution potential. Others argued that food rescue was inefficient in the long run, subsidised wasteful food production practices, and distracted from the need for food systems transformation. Such views reflect the inherent contradictions and debates surrounding food rescue (53).

\subsubsection{Encountering Others Through Food}

Participants noted that the increase in government and philanthropic funding for food services over recent months meant that resources were available in a way they had never experienced before. They described how previous barriers, administrative requirements, and qualifying criteria for emergency food support were removed during Levels $3-4$. The removal of barriers to providing support enabled community food organisations to respond with increased speed and agility. The shift to online deliveries of food where people no longer had to wait in public lines, complete detailed assessments about their personal circumstances, or engage in demeaning interviews led to both a wider range of people seeking support and disrupted discourses of whakamā (shame) and stigma around food insecurity. As one participant commented, "COVID made it an okay reason to ask for help" (regional social service organisation employee).

Participants described how the provision of food through contactless delivery worked to maintain social connections and demonstrate care during levels 3-4. Participants noted how removing barriers increased their capacity to care, which in turn had positive effects on food recipients' wellbeing. For example:

"We physically saw a difference in people as we moved through COVID ... their physical well-being changed, even the guys on the street. Their physical well-being changed just by having someone connect with them, give them a kai and acknowledge that they care about them." (community food organisation volunteer)

The removal of barriers, administrative requirements qualifying criteria cut against neoliberal and racialised discourses in Aotearoa New Zealand that demonise and individualise people experiencing food insecurity [15]. The removal of barriers prompted participants to reflect on how inefficient these previous practices were (for example, screening questionnaires, qualifying criteria). How they reduced 
the ability to actually provide food to people in need, and entrenched feelings of shame and trauma for people seeking food support.

The regional asset and food mapping process served to connect people and food organisations in novel ways. Participants described how they shared information and resources, and increased their support for each other. The following examples from two of our participants illustrate how stronger relationships and new partnerships have emerged in recent months:

"Our first [meeting] on Zoom, there was like 46 of us and it was such a powerful meeting. It was a powerful meeting because it has never happened before, where every food provider and service, or nearly, in Waikato actually met each other for the first time and everybody had a common goal, which was, how do we help people get access to kai [food]. How do we do that safely? It was just beautiful, people were like saying, make sure you go to this website, make sure you get setup there. The conversations were like ping pong, there was this openness to just help each other, set themselves up as essential services and then we had civil defence in that hui [meeting], they were able to say, great, I've got these people I can tap into. So immediately there was these relationships that were built out of need because everybody knew the common goal and we need to go there." (community food organisation volunteer)

"There are loads of us who worked through this on COVID who'd never met each other before and now we're like, best buds!" (regional social service organisation employee)

Participants also described how recent experiences of food insecurity have led to an increased interest in gardening and food production. This involves encountering both other humans and the non-human. For example:

“There was a more embodied [return to the garden after lockdown] with love and-not to romanticise this, but even for people who knew this stuff it became more important. Life changed. What better time than now to get our hands in the dirt." (marae garden worker)

Gibson-Graham, Cameron and Healy [20] argue that economies (even those described as 'capitalist') are actually composed of diverse enterprises, transactions, and practices. They suggest that one way to counter the capitalocentric view that everything is either subsumed by, or in opposition to capitalism, is to make visible and amplify the diversity of existing economic enterprises and transactions that people use to sustain their livelihoods. The examples of procuring and distributing food as detailed by our participants illustrate the range of market, alternative market, and non-market transactions that were enacted during Levels 3-4. Table 2 uses Gibson-Graham, Cameron and Healy's [20] diverse transactions identifier as a framework to summarise the diverse range of transactions that have fostered food security. The examples highlighted in Table 2 are not an exhaustive account of every type of transaction that has occurred around food in Aotearoa New Zealand in recent months. Rather, it is a snapshot of transactions our participants described. 
Table 2. Diverse Transactions Identifier.

\begin{tabular}{|c|c|}
\hline Transaction & Example \\
\hline $\begin{array}{c}\text { Market } \\
\text { Transactions involving exchange of money }\end{array}$ & New Zealanders buying food from supermarkets \\
\hline $\begin{array}{c}\text { Alternative Market } \\
\text { Fair trade and direct trade } \\
\text { Reciprocal exchange } \\
\text { Alternative currency } \\
\text { Local trading system } \\
\text { Community-supported agriculture } \\
\text { Barter } \\
\text { Underground market } \\
\text { Informal market }\end{array}$ & $\begin{array}{l}\text { Supermarkets allowing community organisations to order food through } \\
\text { their supply chains to obtain discounts } \\
\text { Increase in support for community-supported agriculture, urban farms, } \\
\text { community gardens } \\
\text { People bartering/exchanging food 'over the fence', or through informal } \\
\text { networks }\end{array}$ \\
\hline $\begin{array}{c}\text { Non-Market } \\
\text { Household flows } \\
\text { Gift giving } \\
\text { Volunteering } \\
\text { Gleaning } \\
\text { State allocations } \\
\text { Hunting, fishing, gathering }\end{array}$ & $\begin{array}{c}\text { Increase in home gardening and food production, and skills sharing to } \\
\text { promote this } \\
\text { Supermarkets establishing national } \$ 1 \mathrm{M} \text { 'social good' community fund } \\
\text { Donations of food to foodbanks/food parcelling initiatives } \\
\text { Food growers and distributors donating surplus food } \\
\text { Supermarkets working with Volunteer Student Army to distribute } \\
\text { purchased food to vulnerable consumers } \\
\text { Increase of direct harvest of vegetables and fruit in open access } \\
\text { community gardens } \\
\text { Civil Defence/government funding-from direct purchasing of bulk } \\
\text { food to PPE, staff wages, logistics, and infrastructure support } \\
\text { Government funding to support NZFN }\end{array}$ \\
\hline
\end{tabular}

\section{Conclusions: Transforming Aotearoa New Zealand's Food Systems}

For our participants, COVID-19 was seen as a chance to re-think existing food practices. One participant summed it up as, "it's kind of given people permission to [do things differently]" (local government employee). We do not presume to know how things will play out. Participant accounts raise many questions and possibilities. For us at this moment, two key possibilities emerge from this research and we discuss each in turn below.

Firstly, our research highlights the existing diverse food practices already present in Aotearoa New Zealand and makes visible the important market, alternative-market and non-market transactions that go into securing food. Coalescing around food, these diverse transactions link people and organisations, and raise ethical questions about how we manage the commons of food (including food surplus and food waste). Sometimes these different food practices and transactions are seen as the single solution, or in opposition or competition. Should we be advocating for increased incomes so people can purchase food through the market? Or should we train more people to become self-sufficient to grow food and provide secure access to land to reduce dependency on the market and charity? The answer can actually be both of these, and more. A diverse economy framework highlights the interconnected and multiple ways that food security is enacted in Aotearoa New Zealand. Such a framework makes visible the diverse ways in which food security is achieved and supported through local production, local distribution networks and relationships, and food rescue infrastructure that can quickly respond to sudden shocks. Our research illustrates the diversity of food provisioning and procurement and emphasises the need for a range of transactions and responses. The differing life stages, bodily vulnerabilities, incomes, and food preferences combine in various ways to create a diversity of requirements. Communities must have access to a myriad of different tools that they can utilise according to need.

Secondly, our research points to a range of emerging new relationships, practices, and transactions. For-profit enterprises took responsibility to develop new partnerships with government and community organisations to provide food, training, support, and equipment. Community organisations took responsibility and used their local knowledge, networks and relationships to support each other and food insecure people in their communities. These new relationships concern more than donations of food and equipment. They include commitments to ongoing training and professional development of 
staff, knowledge sharing, and the negotiation of ethical questions regarding establishing and managing food commons across the country, as evidenced most clearly by the emergence of the New Zealand Food Network. While we have written about the NZFN in relatively positive ways, we acknowledge the critiques of food rescue-specifically concerns that it is a temporary fix to a structural problem, can perpetuate stigma if food is of poor quality/does not meet recipients' needs, and it does not force the wider agri-food sector to address overproduction.

Participant accounts of Levels 3-4 illustrate how circuits of care and responsibility were activated via new and existing relational networks, where new communities assembled and reassembled, and new ways of being consumers and producers were activated and adjusted. The rapid removal of barrier-free food distribution showed how possible and beneficial it is to understand food as a common good, and to position people as commoners partaking in that good, rather than dependents failing to be good individual consumers reliant on 'charity.' The question remains, why have these barriers remained in place so long, especially given recent increases in rescued surplus food? As Isola and Laihho [53] suggest, the wide availability of surplus food in a market system means that its redistribution is an environmental and economic necessity, rather than some kind of charity or voluntary act. For us, the emergence of the NZFN in particular raises important questions around how more coordinated, national approaches to surplus food could shift political debates about universal access to food [54,55]. We wonder what kinds of care relationships and opportunities will flow from these experiences and relationships? Will we see the further blurring of distinctions between for-profit and not-for-profit enterprises, and movement of staff between different types of organisations? Will we see continued shifts in the ways people learn to be affected by food? Will we see new ways of negotiating a wider food commons in Aotearoa New Zealand, ways which move beyond the limiting discourses of top-down welfare state pitted against neoliberal individualised responsibilities and associated charity and shame? The welfare state and charity are clearly not the only two solutions for those experiencing food insecurity.

These questions prompt us to wonder whether and how the interest in local food supply will continue to manifest. Will it lead to more networked urban farms and community gardens as urban people in particular rediscover their capacity to produce food? We are not suggesting that small-scale production is the only solution to food insecurity which can be easily co-opted by neoliberal discourses of self-sufficiency. People need equal access to food regardless of their individual capacities and resources. However, we wonder what kinds of diverse economic transactions and negotiations around access to land and property will emerge from such practices, and what kinds of outcomes for biodiversity, human wellbeing, and climate will these foster [55-57]? What kinds of policy incentives, funding, education programmes, and new jobs could government, local councils, philanthropists, for-profit organisations, and community organisations develop to support such a diverse food security ecosystem [56]? Additionally, importantly for Aotearoa New Zealand, how can Māori practices of food gathering, distribution, and consumption inform, design, and build a diverse food security ecosystem with Te Tiriti (The Treaty of Waitangi) at its core? The multiple access points to food we have highlighted in this article are all possible approaches in the toolkit moving forward in re-creating a community economy of food security. Aotearoa New Zealand has provided an internationally useful example of how to effectively respond to a global pandemic. We hope that the country can now lead in addressing food security through a justice lens with grounded practices in specific places.

Author Contributions: G.D. conceptualised the paper, drawing on the wider research project designed by K.D. and G.D.; A.W. and K.D. wrote the ethics application, obtained through the University of Canterbury Human Ethics Committee Dombroski HEC2020/25. R.G. in charge of data curation, formal analysis and writing of the original draft. L.L. in charge of data curation and resources. M.S. in charge of conceptualization. S.R. data curation and methodology. R.M.-N. in charge of data curation and writing the original draft. All authors contributed to the research process through conducting and transcribing interviews and reviewing literature. G.D. and E.S. undertook analysis of empirical data and coordinated drafting of the manuscript. All authors contributed to editing the manuscript and approved the final submission. All authors have read and agreed to the published version of the manuscript. 
Funding: Gradon Diprose acknowledges funding through the Resilience to Nature's Challenges National Science Challenge. Kelly Dombroski and Gradon Diprose acknowledge funding through Building Better Homes, Towns and Cities National Science Challenge.

Acknowledgments: We would like to thank our research participants for their time, insights, and commitment to fostering food security in Aotearoa New Zealand.

Conflicts of Interest: The authors declare no conflict of interest.

\section{References}

1. New Zealand Government. Essential Businesses. 2020. Available online: https://web.archive.org/web/ 20200414002409/https://covid19.govt.nz/businesses-and-employees/essential-businesses/ (accessed on 24 June 2020).

2. Strongman, S.; Covid-19 Pandemic Timeline. Radio New Zealand. 2020. Available online: https://shorthand. radionz.co.nz/coronavirus-timeline/ (accessed on 4 September 2020).

3. Henrickson, M. Kiwis and COVID-19: The Aotearoa New Zealand Response to the Global Pandemic. Int. J. Community Soc. Dev. 2020, 2, 121-133. [CrossRef]

4. Knight, D. Law-Making and Accountability in Responding to COVID-19: The Case of New Zealand. In Representation in Democracies During Emergencies Melbourne Forum on Constitution-Building in Asia and the Pacific, Melbourne Law School, Constitution Transformation Network. 2020. Available online: https://law.unimelb.edu.au/_data/assets/pdf_file/0008/3476537/MF20-Web2-NZ-Knight-FINAL.pdf (accessed on 28 August 2020).

5. Martin-Neuninger, R.; Ruby, M.B. What Does Food Retail Research Tell Us About the Implications of Coronavirus (COVID-19) for Grocery Purchasing Habits? Front. Psychol. 2020, 11. [CrossRef]

6. Gibson, P.; Jussi, P. A Geology of Media. Minneapolis: University of Minnesota Press. 206 pp. Crit. Inq. 2016, 42, 983-984. [CrossRef]

7. Alkon, A.H.; Agyeman, J. Cultivating Food Justice: Race, Class and Sustainability; MIT Press: Cambridge, MA, USA, 2011.

8. Rout, M.; Reid, J.; Mika, J. Māori agribusinesses: The whakapapa network for success. Altern. Int. J. Indig. Peoples 2020. [CrossRef]

9. Barr, T.L.; Reid, J.; Catska, P.; Varona, G.; Rout, M. Development of indigenous enterprise in a contemporary business environment-The Ngāi Tahu Ahikā approach. J. Enterprising Communities 2018, 12, 454-471. [CrossRef]

10. Reid, J.; Rout, M. Getting to know your food: The insights of indigenous thinking in food provenance. Agric. Hum. Values 2015, 33, 427-438. [CrossRef]

11. Gibson-Graham, J.; Dombroski, K. The Handbook of Diverse Economies; Edward Elgar Publishing: Cheltenham, UK, 2020.

12. Diprose, G. Framing essay: The diversity of transactions. In The Handbook of Diverse Economies; Edward Elgar Publishing: Cheltenham, UK, 2020; pp. 195-205.

13. Sharp, E.L.; Schindler, E.; Lewis, N.; Friesen, W. Food fights: Irritating for social change among Auckland's alternative food initiatives. Kōtuitui N. Z. J. Soc. Sci. Online 2016, 11, 133-145. [CrossRef]

14. Sharp, E.L. Care-fully enacting diverse foodworlds in Auckland, Aotearoa New Zealand. Gender Place Cult. 2020, 27, 1214-1218. [CrossRef]

15. Graham, R. Food Insecurity and Social Justice in Aotearoa New Zealand. Psychol. Aotearoa 2017, 9, 105-108. Available online: https://www.psychology.org.nz/ (accessed on 13 November 2017).

16. Graham, R.; Hodgetts, D.; Stolte, O.; Chamberlain, K. Food insecurity in urban New Zealand. The case of the Kopa family. J. Poverty 2018, 22, 379-397. [CrossRef]

17. Graham, R.; Hodgetts, D.; Stolte, O.; Chamberlain, K. Hiding in plain sight: Experiences of food insecurity and rationing in New Zealand. Food Cult. Soc. 2018, 21, 384-401. [CrossRef]

18. Hodbod, J.; Eakin, H. Adapting a social-ecological resilience framework for food systems. J. Environ. Stud. Sci. 2015, 5, 474-484. [CrossRef]

19. Sharp, E.L. Editorial: The role of reflexivity in care-full food systems transformations. Policy Futur. Educ. 2019, 17, 761-769. [CrossRef] 
20. Gibson-Graham, J.-K.; Cameron, J.; Healy, S. Take Back the Economy. An Ethical Guide for Transforming Our Communities; University of Minnesota Press: Minneapolis, MN, USA, 2013.

21. Lavrakas, P. Encyclopedia of Survey Research Methods. In Encyclopedia of Survey Research Methods; SAGE Publications: Thousand Oaks, CA, USA, 2008; p. 824.

22. Braun, V.; Clarke, V. Successful Qualitative Research; Sage: London, UK, 2013.

23. FAO. Trade Reforms and Food Security. Rome. 2003. Available online: http://www.fao.org/3/y4671e/ y4671e06.htm\#bm06 (accessed on 5 November 2020).

24. Parnell, W.R.; Gray, A.R. Development of a food security measurement tool for New Zealand households. Br. J. Nutr. 2014, 112, 1393-1401. [CrossRef]

25. Coleman-Jensen, A.J. U.S. Food Insecurity Status: Toward a Refined Definition. Soc. Indic. Res. 2009, 95, 215-230. [CrossRef]

26. Food and Agriculture Organization of the United Nations, Impacts of Coronavirus on Food Security and Nutrition in Asia and the Pacific: Building More Resilient Food Systems. Available online: http: //www.fao.org/3/ca9473en/CA9473EN.pdf (accessed on 5 June 2020).

27. Bush, R. Resisting Poverty and Neoliberalism. In Poverty and Neoliberalism; Pluto: London, UK, 2007; pp. 178-200.

28. Knowles, M.; Rabinowich, J.; De Cuba, S.E.; Cutts, D.B.; Chilton, M. “Do You Wanna Breathe or Eat?": Parent Perspectives on Child Health Consequences of Food Insecurity, Trade-Offs, and Toxic Stress. Matern. Child Heal. J. 2016, 20, 25-32. [CrossRef]

29. Sharp, E.; Matheson, A. Reimagining our food system post Covid-19: Doughnuts and Dandelions. Spinoff 2020, in press.

30. Kc, K.B.; Dias, G.M.; Veeramani, A.; Swanton, C.J.; Fraser, D.; Steinke, D.; Lee, E.; Wittman, H.; Farber, J.M.; Dunfield, K.; et al. When too much isn't enough: Does current food production meet global nutritional needs? PLoS ONE 2018, 13, e0205683. [CrossRef]

31. Rush, E. Aotearoa, Land of the Long Wide Bare Cupboard. Part 1: Fat, Famished or Starved in a Land of Plenty? Available online: https://www.cpag.org.nz/campaigns/the-latest-aotearoa-land-of-the-long-wide/ (accessed on 7 November 2019).

32. Statistics New Zealand. Food Price Index: June 2020. Available online: https://www.stats.govt.nz/ information-releases/food-price-index-june-2020 (accessed on 12 July 2020).

33. Ministry of Health. Household Food Insecurity among Children: New Zealand Health Survey | Ministry of Health NZ. 2019. Available online: https://www.health.govt.nz/publication/household-food-insecurityamong-children-new-zealand-health-survey (accessed on 12 June 2019).

34. Murray, S. The State of Wellbeing and Equality for Disabled People, Their Families, and Whānau. 2019. Available online: https://ccsdisabilityaction.org.nz/news-and-views/news/radical-reform-needed-to-savedisabled-children-from-poverty-new-report-reveals-worsening-picture/ (accessed on 4 December 2019).

35. Ministry of Health. A Focus on Nutrition: Key Findings from the 2008/09 NZ Adult Nutrition Survey | Ministry of Health NZ. 2012. Available online: https://www.health.govt.nz/publication/focus-nutrition-keyfindings-2008-09-nz-adult-nutrition-survey (accessed on 5 November 2020).

36. Robinson, H. Shining a Light on Food Insecurity in Aotearoa New Zealand [ResearchSpace@Auckland]. 2019. Available online: https://researchspace.auckland.ac.nz/handle/2292/50490 (accessed on 5 November 2020).

37. Pearce, J.R.; Day, P.; Witten, K. Neighbourhood Provision of Food and Alcohol Retailing and Social Deprivation in Urban New Zealand. Urban Policy Res. 2008, 26, 213-227. [CrossRef]

38. Witten, K.; Pearce, J.R.; Day, P. Neighbourhood Destination Accessibility Index: A GIS Tool for Measuring Infrastructure Support for Neighbourhood Physical Activity. Environ. Plan. A 2011, 43, 205-223. [CrossRef]

39. Sushil, Z.; Vandevijvere, S.; Exeter, D.J.; Swinburn, B. Food swamps by area socioeconomic deprivation in New Zealand: A national study. Int. J. Public Heal. 2017, 62, 869-877. [CrossRef] [PubMed]

40. Waka Kotahi NZ Transport Agency. Keeping Cities Moving. 2019. Available online: https://www.nzta.govt. nz/assets/resources/keeping-cities-moving/Keeping-cities-moving.pdf (accessed on 13 September 2019).

41. Curl, A.; Watkins, A.; McKerchar, C.; Exeter, D.; Macmillan, A. Social Impact Assessment of Mode Shift; Waka Kotahi NZ Transport Agency: Wellington, New Zealand, 2020; 113p.

42. Ministry of Social Development. N.D. Food Secure Communities. Available online: https://www.msd.govt. nz/what-we-can-do/community/food-secure-communities/index.html (accessed on 5 November 2020). 
43. Sharp, E.L.; Friesen, W.; Lewis, N. Alternative framings of alternative food: A typology of practice. N. Z. Geogr. 2015, 71, 6-17. [CrossRef]

44. Diprose, G. Policing art: The political potential of creative practices in Aotearoa New Zealand. In Engaging Geographies: Landscapes Life Courses, and Mobilities; Roche, M., Prince, R., Eds.; Cambridge Scholars Press: Newcastle, UK, 2014.

45. Hodgetts, D.; Stolte, O. Urban Poverty and Health Inequalities; Informa UK Limited: London, UK, 2017.

46. Allahyari, R.A.; Poppendieck, J. Sweet Charity? Emergency Food and the End of Entitlement. Contemp. Sociol. A J. Rev. 1999, 28, 457-458. [CrossRef]

47. Cloke, P.; May, J.; Williams, A. The geographies of food banks in the meantime. Prog. Hum. Geogr. 2016, 41, 703-726. [CrossRef]

48. Cameron, J.; Manhood, C.; Pomfrett, J. Bodily learning for a (climate) changing world: Registering differences through performative and collective research. Local Environ. 2011, 16, 493-508. [CrossRef]

49. Robson, S. It's Christmas on Steroids'-Foodbanks in Huge Demand across NZ. 2020. Available online: https: //www.rnz.co.nz/news/national/414809/it-s-christmas-on-steroids-foodbanks-in-huge-demand-across-nz (accessed on 22 April 2020).

50. The Salvation Army. Online Foodbank Ramps up for Covid-19 Response. 2020. Available online: https: //www.salvationarmy.org.nz/news/online-foodbank-ramps-covid-19-response (accessed on 1 April 2020).

51. Cradock-Henry, A.; Fountain, N.; Buelow, J.; Cradock-Henry, F.N. Transformations for Resilient Rural Futures: The Case of Kaikōura, Aotearoa-New Zealand. Sustainability 2018, 10, 1952-1971. [CrossRef]

52. Taunton, E. Coronavirus: Govt Buying 2000 Pigs a Week as Industry Struggles with Surplus. 2020. Available online: https://www.stuff.co.nz/business/121570742/coronavirus-govt-buying-2000-pigs-a-weekas-industry-struggles-with-surplus (accessed on 21 May 2020).

53. Isola, A.; Laiho, J. Comoning surplus food in Finland-actors and tensions. In Enacting Community Economies Within a Welfare State; Eskelinen, T., Hirvilammi, T., Venäläinen, J., Eds.; Mayfly Books: Newcastle, UK, 2020.

54. Graham, R.; Stolte, O.; Hodgetts, D.; Chamberlain, K. A food secure New Zealand. Int. Perspect. Psychol. Res. Pr. Consult. 2019, 8, 103-106. [CrossRef]

55. Hyvärinen, P. Building upon, extending beyond: Small scale food production within a Nordic welfare state. In Enacting Community Economies Within a Welfare State; Eskelinen, T., Hirvilammi, T., Venäläinen, J., Eds.; Mayfly Books: Newcastle, UK, 2020.

56. Nicholls, E.; Ely, A.; Birkin, L.; Basu, P.; Goulson, D. The contribution of small-scale food production in urban areas to the sustainable development goals: A review and case study. Sustain. Sci. 2020, 1-15. [CrossRef]

57. Birtalan, I.L.; Bartha, A.; Neulinger, A.G.B.; Oláh, A.; Rácz, J.G.; Rigó, A. Community Supported Agriculture as a Driver of Food-Related Well-Being. Sustainability 2020, 12, 4516. [CrossRef]

Publisher's Note: MDPI stays neutral with regard to jurisdictional claims in published maps and institutional affiliations.

(C) 2020 by the authors. Licensee MDPI, Basel, Switzerland. This article is an open access article distributed under the terms and conditions of the Creative Commons Attribution (CC BY) license (http://creativecommons.org/licenses/by/4.0/). 